\section{Exponential smoothing for intermittent demand with demand basis updated more frequently than seasonality factors}

\section{Suavização exponencial para demanda intermitente com fatores de sazonalidade considerando períodos maiores do que os usados para atualizar a base da demanda}

\author{
Jorge Luiz de Biazzi ${ }^{1}$
}

ISSN 0104-530X (Print) ISSN 1806-9649 (Online)

How to cite: Biazzi, J. L. (2019). Exponential smoothing for intermittent demand with demand basis updated more frequently than seasonality factors. Gestão \& Produção, 26(1), e1297. https://doi.org/10.1590/0104-530X1297-19

\begin{abstract}
This study aims to present an alternative technique of exponential smoothing to estimate the demand for items with intermittent and seasonal demand. The usual technique would aggregate demand periods (months in quarters, for instance) to calculate a seasonality factor for the set of periods. The estimate for the set would be divided by the number of periods comprising it to calculate the demand per period. This technique recalculates the basis and seasonality factor for each set, and provides equal estimates for all periods within the set. The alternative herein presented also recalculates seasonal factors for every set of periods, but recalculates the demand basis for each period, allowing better monitoring of demand behavior. Based on a real-life case, the results obtained by the two techniques mentioned above and by others that do not explicitly consider seasonality were compared: simple moving average, no-seasonality exponential smoothing, Croston's, and Syntetos-Boylan. The latter two were developed specifically for intermittent demands without seasonality. The techniques that consider seasonality performed better for estimation errors. The suggested technique, in the example, showed less bias, although with somewhat lower accuracy than exponential smoothing with seasonality and period aggregation.
\end{abstract}

Keywords: Exponential smoothing; Intermittent demand; Seasonality.

Resumo: Este estudo tem como objetivo apresentar uma técnica alternativa de suavização exponencial para estimar a demanda de itens com demanda intermitente e sazonal. A técnica usual consiste em agregar alguns periodos (meses agregados em trimestres, por exemplo) e calcular um fator de sazonalidade para o conjunto e, após fazer a estimativa para este, dividir pela quantidade de períodos que o compõe para calcular a demanda por periodo. Esta técnica, que recalcula base e fator de sazonalidade a cada conjunto de periodos, resulta em estimativas iguais para todos os periodos do conjunto. A alternativa apresentada também recalcula fatores de sazonalidade a cada conjunto de periodos, mas recalcula a base da demanda a cada periodo, permitindo acompanhar o comportamento da demanda com frequência maior. A partir de um caso real, foram comparados os resultados obtidos para as duas técnicas mencionadas e para outras que não consideram explicitamente a sazonalidade: média móvel sem sazonalidade, suavização exponencial sem sazonalidade, Croston e Syntetos-Boylan. Estas duas últimas foram desenvolvidas para demandas intermitentes, mas sem sazonalidade. As técnicas que consideram sazonalidade tiveram melhor desempenho em relação aos erros de estimação. A técnica sugerida apresentou, no exemplo utilizado, menos viés, embora com uma precisão um pouco menor do que a suavização exponencial com sazonalidade e agregação de períodos.

Palavras-chave: Suavização exponencial; Demanda intermitente; Sazonalidade.

\section{Introduction}

Exponential smoothing is a demand forecasting technique widely used for short-term forecasts, given its relative simplicity and results that are as appropriate as or even better than more sophisticated techniques, like multiple regression and Box-Jenkins (Gardner, 1985; Dekker et al., 2004). In the hypotheses of seasonality, with or without demand growth (or reduction) trend in the long term, seasonality

${ }^{1}$ Universidade de São Paulo - USP, Av. Prof. Luciano Gualberto, 908, CEP 05508-010, São Paulo, SP, Brasil, e-mail: jlbiazzi@usp.br Received Feb. 25, 2017 - Accepted Jan. 7, 2018

Financial support: None. 
factors are applied to the demand estimated for a given period, thus correcting forecasts in relation to an average behavior. Usually, there is one seasonality factor for each reference demand period. For example, if demands for one item are recorded on a monthly basis, there will be a seasonality factor for each month of the year. If demands are recorded on a weekly basis, there will be one seasonality factor for each week of the year. In both cases, the item could have annual seasonality, that is, values above and below the average behavior would have a repetition pattern each year, like, for example, demand for ice-cream in Brazil (Codogno, 2016).

Intermittent demand items are those items whose demands have low averages and do not occur as regularly nor as frequently as demand for sugar or oil in supermarkets (Wanke, 2003; Ballou, 2006). Replacement parts for machines and vehicles are classical examples of intermittent demand items. Some of them certainly present demand seasonality due to replacement needs more significant at certain times of the year, like filters and windshield wiper blades. In these cases, even if at the same time of the year, items may have time periods with very low demands (possibly zero) alternating with not-so-low demand periods (five units or fifteen units, for example).

The usual exponential smoothing techniques, as they consider seasonality factors for each reference period in the demand history, may not work appropriately for intermittent demand items, because they would create an artificial seasonality for each period. Table 1 shows an example of a hypothetical demand history of one item with intermittent demand.

According to the usual logic of seasonality calculation, the model would create a seasonality factor for each month of the year. Assuming multiplicative seasonality and an average close to 5 units/month, month $4 / 2010$ would have a seasonality factor close to $((5+10) / 2) / 5)=1.5$ (indicating that, in 2010, the demand for this month would be 1.5 times the average monthly demand), while months 5/2010 and $6 / 2010$ would have factors respectively close to $((0+5) / 2) / 5)=0.5$ and $((10+0) / 2 / 5)=1.0$. Demand forecasting for the same months of 2010, therefore, would be, respectively, 7.5, 2.5 and 5 units. This forecast, however, does not make much sense because demand oscillations around the average may be just random, and not be part of a behavior pattern that is likely to repeat in the future.
To avoid this inadequate forecasting process, we may think of grouping many months into a larger reference period, for example, a set of 3 months. In this manner, seasonality factors could be calculated for each quarter, and we would assume the hypothesis that every month of the set would have the same demand forecast (the demand forecast for the quarter divided by the number of months in the set). In the example, the set of 3 months would have factor 1.0, the demand estimate for the quarter would be 15 units and the estimate for each month would be 5. Such grouping would generate abrupt changes in demand forecasting because every 3 months there would be a new seasonality factor.

Intermediate situations, like using two months as the reference, could smooth these abrupt changes, but there would be risk of getting to such short reference periods that the initial problem (of having artificial seasonality factors) could return. The problem of the aggregation is that, to avoid this artificial seasonality, too long sets could be formed, requiring a long time to refresh the demand basis, and these updates would only be done, by the traditional technique, at the end of the set of 3 months.

This article has the goal of presenting a novel approach to forecast demand of items with intermittent demand with seasonality. This novel approach is based on the logic of using seasonality factors for sets of periods but to allow updating the demand basis every period. For example, every month the parameter used to estimate the demand basis would be recalculated while seasonality factors would be updated only every 3 months.

Differently from the conventional approach of aggregating demand for three months into a quarterly demand, and estimating each one of the following months as $1 / 3$ of the quarterly demand, which could lead to a very slow demand basis adjustment (as the correction of the basis would be made every three months), the approach herein suggested permits correcting the basis every month. In this manner, forecasting will possibly be in better synchrony with actual demand, with smaller errors in estimates.

The results obtained with the suggested technique were compared to the results of the techniques of basic exponential smoothing, Croston's, and Syntetos-Boylan, in terms of Mean Absolute Deviation and Mean Deviation, and these errors in relation to 2-year average demand.

Table 1. Partial demand history of one item.

\begin{tabular}{ccccccc}
\hline Month/Year & $\mathbf{4 / 2 0 0 8}$ & $\mathbf{5 / 2 0 0 8}$ & $\mathbf{6 / 2 0 0 8}$ & $\mathbf{4 / 2 0 0 9}$ & $\mathbf{5 / 2 0 0 9}$ & $\mathbf{6 / 2 0 0 9}$ \\
\hline Demand (units) & 5 & 0 & 10 & 10 & 5 & 0 \\
\hline
\end{tabular}

Source: Prepared by the author. 


\section{Theoretical foundations}

The basic demand forecasting concepts and techniques are presented by Bowersox \& Closs (2001), Chase et al. (2006), Chopra \& Meindl (2003), Krajewski et al. (2009) and Makridakis et al. (1998), including projection, the logic associated to exponential smoothing. In projection, past behavior is assumed to repeat in the future, and the only explanatory variable is time (Equation 1).

$$
V(t)=f(t)+\xi \times \sigma_{v}(t)
$$

where $V(t)$ is the actual demand for a product; the $f(t)$ components are basis, trend, seasonality, and, in some cases, cyclicity (longer cycles than seasonal cycles); component $\xi \times \sigma_{\mathrm{v}}(\mathrm{t})$ corresponds to the randomness of item demand.

Table 2 presents the projection equations for some of the demand behavior hypotheses, for cases of additive trend and multiplicative seasonality (when trend and seasonality exist).

There are two basic techniques to estimate the values of the parameters of projection equations: moving average (which considers values of the demand history as equally important), and exponential smoothing, which considers more relevant the most recent values of the history.

In exponential smoothing, for the hypotheses in Table 2, the parameters of the projection equation are calculated as indicated in Table 3.

Gardner (2006) presents a full list of exponential smoothing techniques developed until 2006, including from the simplest one (Brown, Holt and Winters, presented in Tables 2 and 3) to the most recent (with damping trend). He also mentions that many studies have been conducted to compare exponential smoothing to ARIMA techniques (auto-regressive integrated moving average) and state-space models, but without conclusive results on which would be the most adequate for each situation, in addition to indicating that many of the techniques would be mathematically equivalent.

Croston (1972) presented a technique for intermittent demand (which would be used instead of Brown's basic exponential smoothing technique):

Demand estimate is given by Equation 2:

$$
Y_{t}=Z_{t} / P_{t}
$$

To update parameters, would be used Equations 3 to 8 :

$$
\begin{aligned}
& \text { If } \mathrm{y}_{\mathrm{t}}=0, \\
& Z_{t}=Z_{t-1} \\
& P_{t}=P_{t-1} \\
& q_{t}=q_{t-1}+1 \\
& \text { If } \mathrm{y}_{\mathrm{t}}>0 \\
& Z_{t}=Z_{t-1}+\alpha \times\left(y_{t}-Z_{t-1}\right) \\
& P_{t}=P_{t-1}+\alpha \times\left(q_{t}-P_{t-1}\right) \\
& q_{t}=1
\end{aligned}
$$

where $Y_{t}$ is demand forecast; $-Z_{t}$ is Croston's estimate of the average demand size (when it occurs); $P_{t}$ is the estimate of the average interval between "non-zero"

Table 2. Projection equations for the most common demand behavior hypotheses.

\begin{tabular}{cc}
\hline Hypothesis & Projection equation \\
\hline Stability & $\mathrm{E}(\mathrm{t})=\mathrm{S}\left(\mathrm{t}_{0}\right)$ \\
Trend & $\mathrm{E}(\mathrm{t})=\mathrm{S}\left(\mathrm{t}_{0}\right)+\left(\mathrm{t}-\mathrm{t}_{0}\right) \times \mathrm{R}\left(\mathrm{t}_{0}\right)$ \\
Seasonality with stability & $\mathrm{E}(\mathrm{t})=\mathrm{F}_{\mathrm{p}}\left(\mathrm{t}_{0}\right) \times \mathrm{S}\left(\mathrm{t}_{0}\right)$ \\
Seasonality with trend & $\mathrm{E}(\mathrm{t})=\mathrm{F}_{\mathrm{p}}\left(\mathrm{t}_{0}\right) \times\left[\mathrm{S}\left(\mathrm{t}_{0}\right)+\left(\mathrm{t}-\mathrm{t}_{0}\right) \times \mathrm{R}\left(\mathrm{t}_{0}\right)\right]$ \\
\hline
\end{tabular}

$\mathrm{t}=$ period; $\mathrm{t}_{0}=$ last period of the series; $\mathrm{E}(\mathrm{t})=$ demand estimate; $\mathrm{S}\left(\mathrm{t}_{0}\right)=$ current basis; $\mathrm{R}\left(\mathrm{t}_{0}\right)=$ current trend; $\mathrm{F}_{\mathrm{p}}\left(\mathrm{t}_{0}\right)=$ seasonality factors corresponding to the cycle periods. Source: Prepared by the author.

Table 3. Update of projection equation parameters for exponential smoothing.

\begin{tabular}{cc}
\hline Hypothesis & Equations for parameter update \\
\hline Stability & $\mathrm{S}\left(\mathrm{t}_{0}\right)=\alpha \times \mathrm{V}\left(\mathrm{t}_{0}\right)+(1-\alpha) \times \mathrm{E}\left(\mathrm{t}_{0}\right)$ \\
Trend & $\mathrm{S}\left(\mathrm{t}_{0}\right)=\alpha \times \mathrm{V}\left(\mathrm{t}_{0}\right)+(1-\alpha) \times \mathrm{E}\left(\mathrm{t}_{\mathrm{t}}\right)$ \\
& $\mathrm{R}\left(\mathrm{t}_{0}\right)=\beta \times\left[\mathrm{S}\left(\mathrm{t}_{0}\right)-\mathrm{S}\left(\mathrm{t}_{0}-1\right)\right]+(1-\beta) \times \mathrm{R}\left(\mathrm{t}_{0}-1\right)$ \\
Seasonality with stability & $\mathrm{S}\left(\mathrm{t}_{0}\right)=\alpha \times \mathrm{V}\left(\mathrm{t}_{0}\right) / \mathrm{F}_{\mathrm{p}}\left(\mathrm{t}_{\mathrm{t}}-\mathrm{P}\right)+(1-\alpha) \times \mathrm{S}\left(\mathrm{t}_{0}-1\right)$ \\
& $\mathrm{F}_{\mathrm{p}}\left(\mathrm{t}_{0}\right)=\gamma \times \mathrm{V}\left(\mathrm{t}_{0}\right) / \mathrm{S}\left(\mathrm{t}_{0}\right)+(1-\gamma) \times \mathrm{F}_{\mathrm{p}}\left(\mathrm{t}_{0}-\mathrm{P}\right)$ \\
Seasonality with trend & $\mathrm{S}\left(\mathrm{t}_{0}\right)=\alpha \times \mathrm{V}\left(\mathrm{t}_{0}\right) / \mathrm{F}_{\mathrm{p}}\left(\mathrm{t}_{0}-\mathrm{P}\right)+(1-\alpha) \times \mathrm{E}\left(\mathrm{t}_{0}\right) / \mathrm{F}_{\mathrm{p}}\left(\mathrm{t}_{0}-\mathrm{P}\right)$ \\
& $\mathrm{R}\left(\mathrm{t}_{0}\right)=\beta \times\left[\mathrm{S}\left(\mathrm{t}_{0}\right)-\mathrm{S}\left(\mathrm{t}_{0}-1\right)\right]+(1-\beta) \times \mathrm{R}\left(\mathrm{t}_{0}-1\right)$ \\
& $\left.\mathrm{F}_{\mathrm{p}}\left(\mathrm{t}_{0}\right)=\gamma \times \mathrm{V}\left(\mathrm{t}_{0}\right) / \mathrm{S}\left(\mathrm{t}_{0}\right)+(1-\gamma) \times \mathrm{F}_{\mathrm{p}} \mathrm{t}_{0}-\mathrm{P}\right)$ \\
\hline
\end{tabular}

$\alpha, \beta, \gamma=$ smoothing coefficients; $\mathrm{P}=$ number of periods in each cycle. Source: Prepared by the author. 
transactions; $y_{t}$ is the "non-zero" value observed in the period; $\mathrm{q}_{\mathrm{t}}$ is the time interval since the last demand; $\alpha$ is the smoothing coefficient of the series level.

Syntetos \& Boylan $(2001,2005)$ proposed a less biased version of Croston's technique and reached even better results for intermittent demands. The projection equation (Equation 9) for application of Syntetos and Boylan's technique is:

$$
Y_{t}=(1-\alpha / 2) \times Z_{t} / P_{t}
$$

Rego \& Mesquita (2011) mention comparative studies with the utilization of the above mentioned techniques (Croston is likely to be better than the weighed moving average and double exponential smoothing, and Syntetos-Boylan is better than the first).

Willemain et al. (2004) suggest using the bootstrapping technique (which, based on estimates, in a Markovian process, of having zero or non-zero demands, random generation would be made around actual values, in case of non-zero demand). Gould et. al. (2008) and Taylor (2010) suggest techniques for multiple seasonalities that will not be considered herein.

Dekker et al. (2004) suggest aggregating items in families to calculate smoothing coefficients because these families would have greater accuracy to establish them. Yelland (2010) considers building families of items with similar life cycles, in order to use the demand behavior of items previously launched as a basis to estimate demand for items that were launched later. Yager (2013) presents a technique where different weights are attributed to the data of the series.

For the evaluation of forecasting techniques, the indicators suggested most often (Gardner, 2006; De Gooijer \& Hyndman, 2006, and others) are based on the deviation (error) of the estimate made in the period immediately before (Equation 10):

$$
\text { Deviation }=V(t)-E(t)
$$

Mean Deviation, which close to zero indicates small bias, is calculated as showed in Equation 11:

$$
\text { Mean Deviation }=\Sigma[V(t)-E(t)] / T
$$

Mean Absolute Deviation, which close to zero indicates accuracy, is calculated as showed in Equation 12:

$$
\text { Mean Absolute Deviation }=\sum|V(t)-E(t)| / T
$$

Mean Squared Error (and its square root), which close to zero indicate accuracy, is calculated as showed in Equation 13:

$$
\text { Mean Squared Error }=\Sigma[V(t)-E(t)]^{2} / T
$$

Silver et al. (1998) recommend the two last ones because they are directly related to the standard deviation of estimation errors, the basis for calculating safety inventories. The Mean Absolute Relative
Deviation (Equation 14) cannot be applied because of possibly null demands (Willemain et al., 2004).

Mean Absolute Relative Deviation $=\Sigma\{|V(t)-E(t)| / V(t)\} / T$

The literature search did not produce any publications contemplating the proposal of this study, that is, demand basis being updated more frequently than the seasonality factors for items with intermittent demand.

\section{Methodology}

As this study intends to merely introduce the technique (and not compare it extensively to others for large numbers of items), it is in the format of a case study, based on an item with the previously mentioned features: its demand is sporadic (even with the monthly basis presented) and there is clear seasonality. Demand values are real; it is a replacement item in the sugar-alcohol industry, used in Biazzi \& Vital (2013), a study that tested simple exponential smoothing, moving average, Croston, and Syntetos-Boylan techniques.

The hypothesis that the proposed forecasting technique might be useful was tested using a mathematical model for the evaluation of estimation errors. The model was build in an electronic spreadsheet which permitted comparing the results provided by the use of several forecasting techniques based on exponential smoothing, in addition to moving average.

In this study, we chose to calculate error as estimate minus demand; in this manner, positive values of mean errors indicate that the forecasting method is biased up, that is, it is likely to overestimate future demand.

In addition to the Mean Absolute Deviation (MAD), we used Mean Deviation (to indicate bias) and MAD values divided by average demand for 24 months and Mean Deviation divided by average demand for 24 months, for a relative understanding of estimate errors.

The initialization of Croston's and Syntetos-Boylan techniques considered the 12 months of 2010. The initial " $\mathrm{Zt}$ " is the average of non-null demands. The initial " $\mathrm{Pt}$ " is the average interval between non-null demands.

Several combinations of smoothing coefficient values were tested (between 0.05 and 0.3 , with a 0.05 step). Calculations are not shown, but comparisons are similar to those presented, which used values that led to smaller mean absolute deviations.

\section{The smoothing technique proposed}

The hypothesis adopted is of seasonality with stability, that is, a possible trend along years is not explicitly considered. The calculation of the projection equation parameters, showed in Equation 15, is based on the following steps:

$$
E\left(t_{0+1}\right)=F_{p}\left(t_{0}+1\right) \times S\left(t_{0}\right)
$$


a) To start the estimation process, aggregate demands are calculated for the semesters of the first year. The average between semi-annual demands provides the semestral basis $\left(\mathrm{St}_{\text {semestral }}\right)$ to calculate semestral seasonality factors $\left(\mathrm{F}_{\mathrm{p}}\right)$. The seasonality factor for the first semester is equal to the demand of the first six months divided by this average. The monthly basis (St) of the last month of the initialization period is the simple average of the 12 months.

b) The monthly basis ( $\mathrm{St}$ ) is updated every new monthly demand, following the usual equation (Equation 16):

$$
S\left(t_{0}\right)=a \times V\left(t_{0}\right) / F_{p}\left(t_{0}\right)+(1-a) \times S\left(t_{0}-1\right)
$$

c) Demand estimate is based on the Equation 17:

$$
E\left(t_{0+1}\right)=F_{p}\left(t_{0}+1\right) \times S\left(t_{0}\right)
$$

One should note that $F_{p}$ is repeated until it has a new value, obtained as indicated in item (d).

d) When the semester is over, a new semestral basis is calculated, with the usual equation, but considering aggregation (in this case six months), as showed in Equation 18:

$S t_{\text {semestral }}=a \times V_{\text {semestral }} / F_{p}\left(t_{0}-P\right)+(1-a) \times S t_{\text {semestral }}$ previous

A new seasonality factor is also calculated for the just-ended semester (the other factor remains the same). The equation follows the conventional formula, aggregating values for the semestral basis (Equation 19):

$$
F_{p}\left(t_{0}\right)=\gamma \times V_{\text {semestral }}\left(t_{0}\right) / S t_{\text {semestral }}+(1-\gamma) \times F_{p}\left(t_{0}-P\right)
$$

A single alpha smoothing coefficient may be used to update $\mathrm{St}$ and $\mathrm{S}_{\text {tsemestral }}$ or two coefficients may be used.

\section{Results}

This study considered an $\alpha^{\prime}$ coefficient to update the semestral basis. As previously mentioned, coefficient values were sought to generate the smallest MAD (in all techniques). Just to make it clear that $\alpha$ does not have to be equal to $\alpha$, we chose to leave $\alpha$ ' equal to 0.1 (the difference between the MAD found to the best $\alpha^{\prime}, 0.05$, is lower than $0.1 \%$ ). Semesters were aggregated in the following way: the first semester is formed by the months of November to April; the second from May to October. This was the aggregation because it seems that the replacements of this type of part are usually greater in the so-called first semester and smaller in the second semester, because of decisions of the consumer market. Other aggregations could be tested (quarterly, four-monthly), but this study will not make the comparisons with the results generated by such alternatives. As in the original demand database there was no demand for the months of November and December of 2009, they were considered equal to the demands of November and December de 2010. Errors were calculated for the horizon of 24 months. Their average values are in the lower part of Chart 1.

Chart 1 presents the calculations of estimates and deviations for the technique proposed, i.e., to update the basis monthly and update the seasonality factor every six months. Chart 2 presents the calculations for the traditional technique of semestral updates for the basis and seasonality factor. In this case, each month estimate is equal to $1 / 6$ of the semestral demand estimate. Chart 3 presents the calculations for the techniques of 12-month moving average and exponential smoothing with stability hypothesis. Chart 4 presents the calculations for Croston's technique. Chart 5 presents the calculations for Syntetos-Boylan technique. We did not seek optimal values for each technique parameter (which has minimized some of the errors calculated). However, we sought the same values for smoothing coefficients in many techniques, so that there was a fairer comparison.

Figure 1 presents demands and estimates made with the various techniques. Table 4 presents a comparative summary of the results of each model we tested.

The outcomes of the techniques of simple exponential smoothing (without seasonality), Croston's and Syntetos-Boylan were practically the same. The 12-month moving average, as expected, kept estimates practically constant (as seasonality is annual, values of one year before would be replaced by another that was almost the same). Moving averages of less than 12 months were not evaluated; oscillations in estimates would be checked, but always with a gap.

The two techniques that consider seasonality yielded results close to and better than those of the other techniques. Exponential smoothing

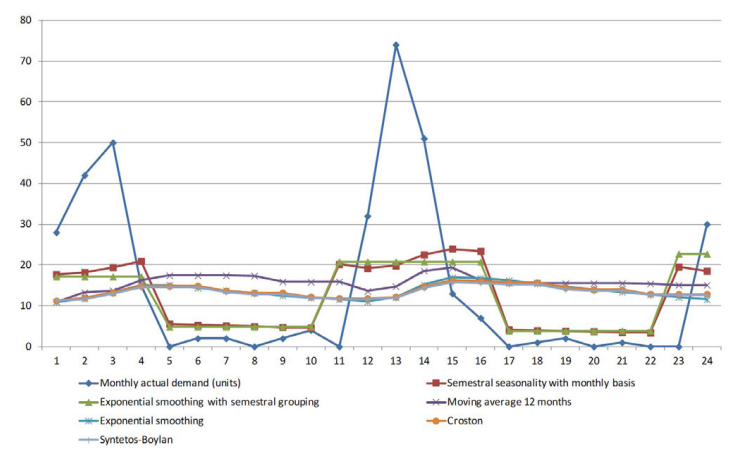

Figure 1. Actual and estimated demand for 24 months (2011 and 2012), in units/month. Source: Prepared by the author. 


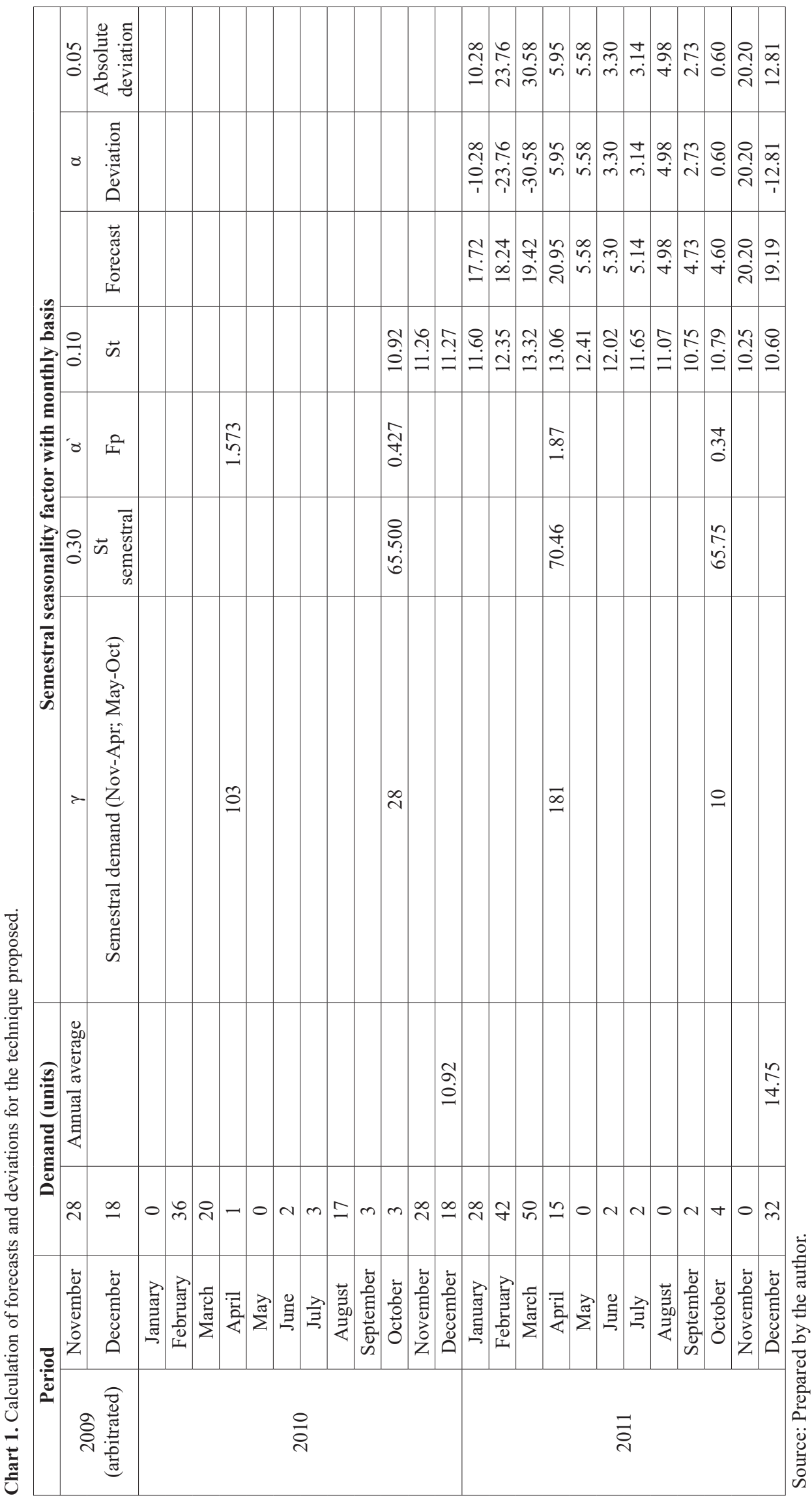




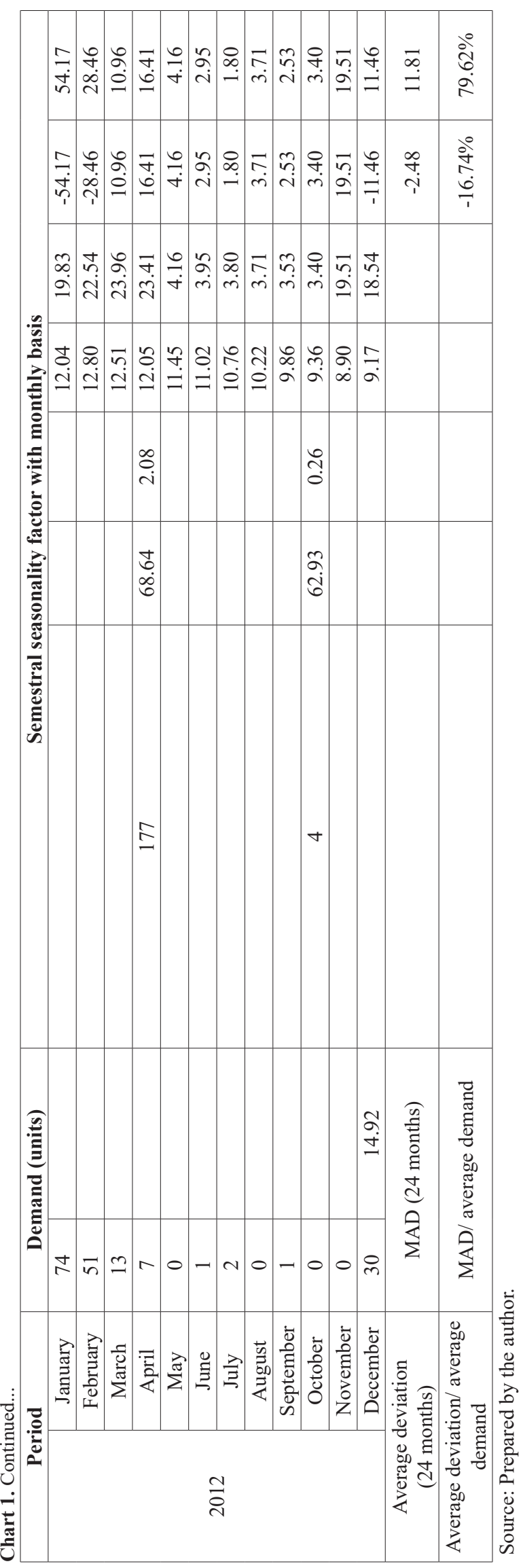




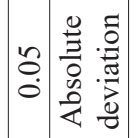

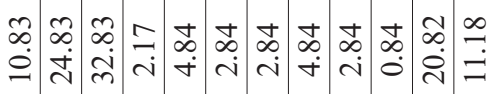

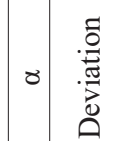

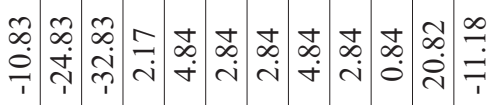

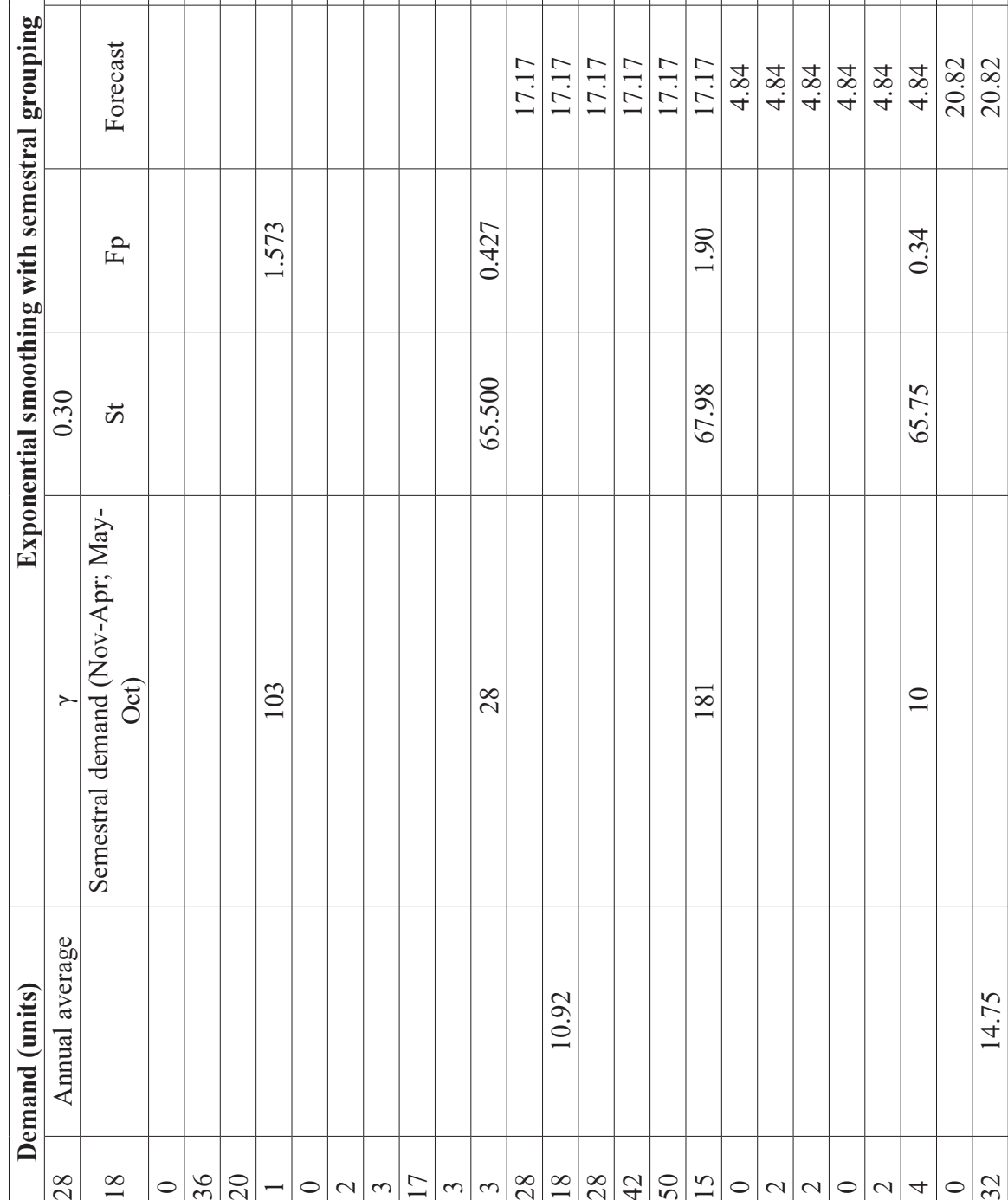

$\underset{n}{\infty}$ o

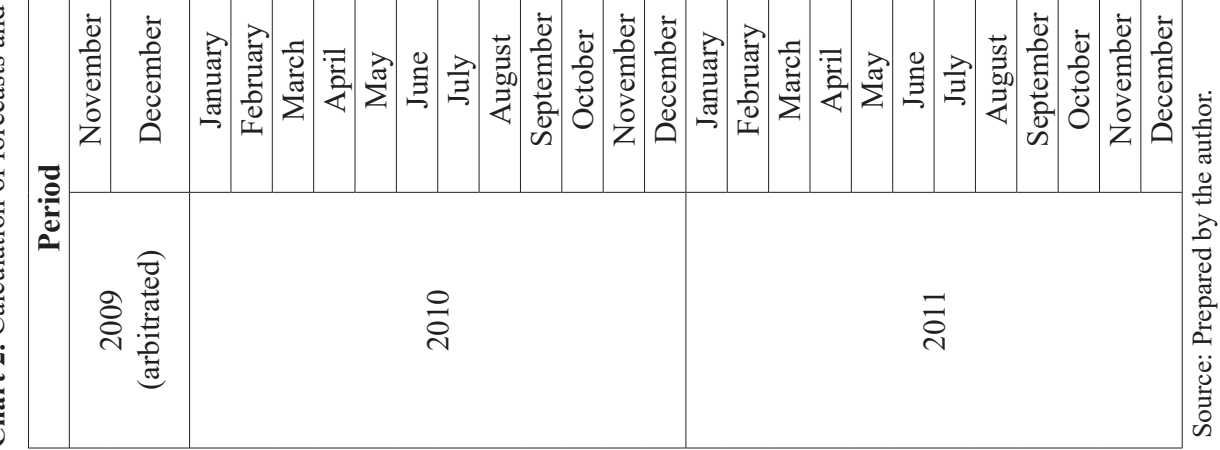




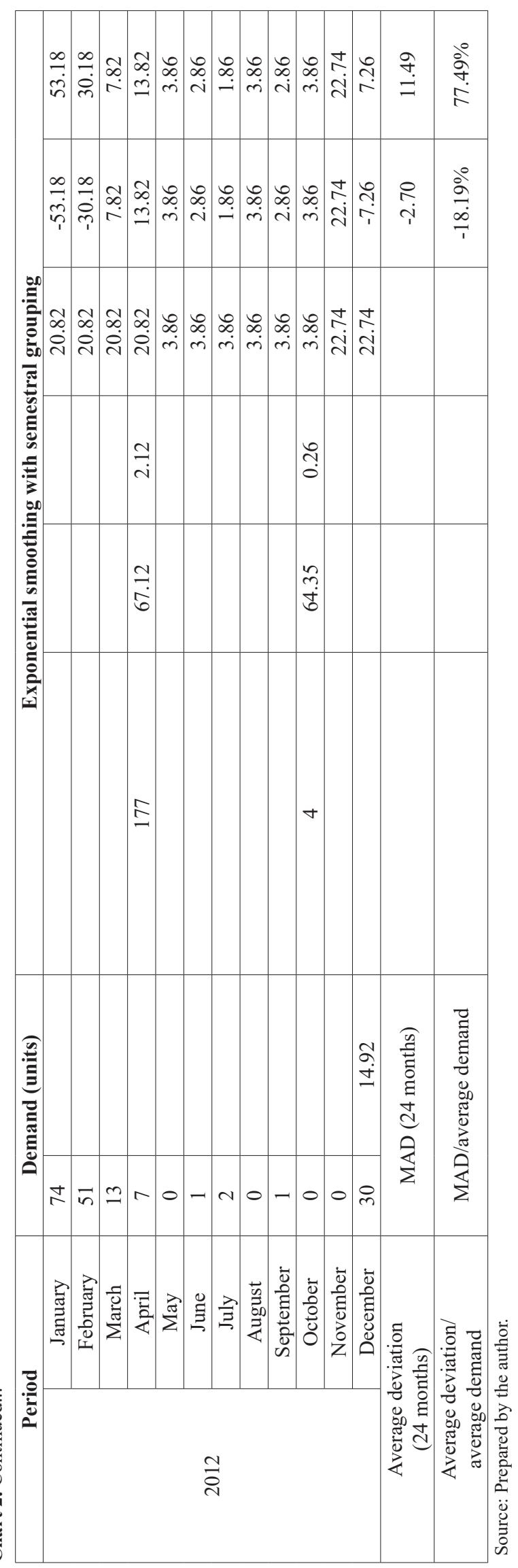




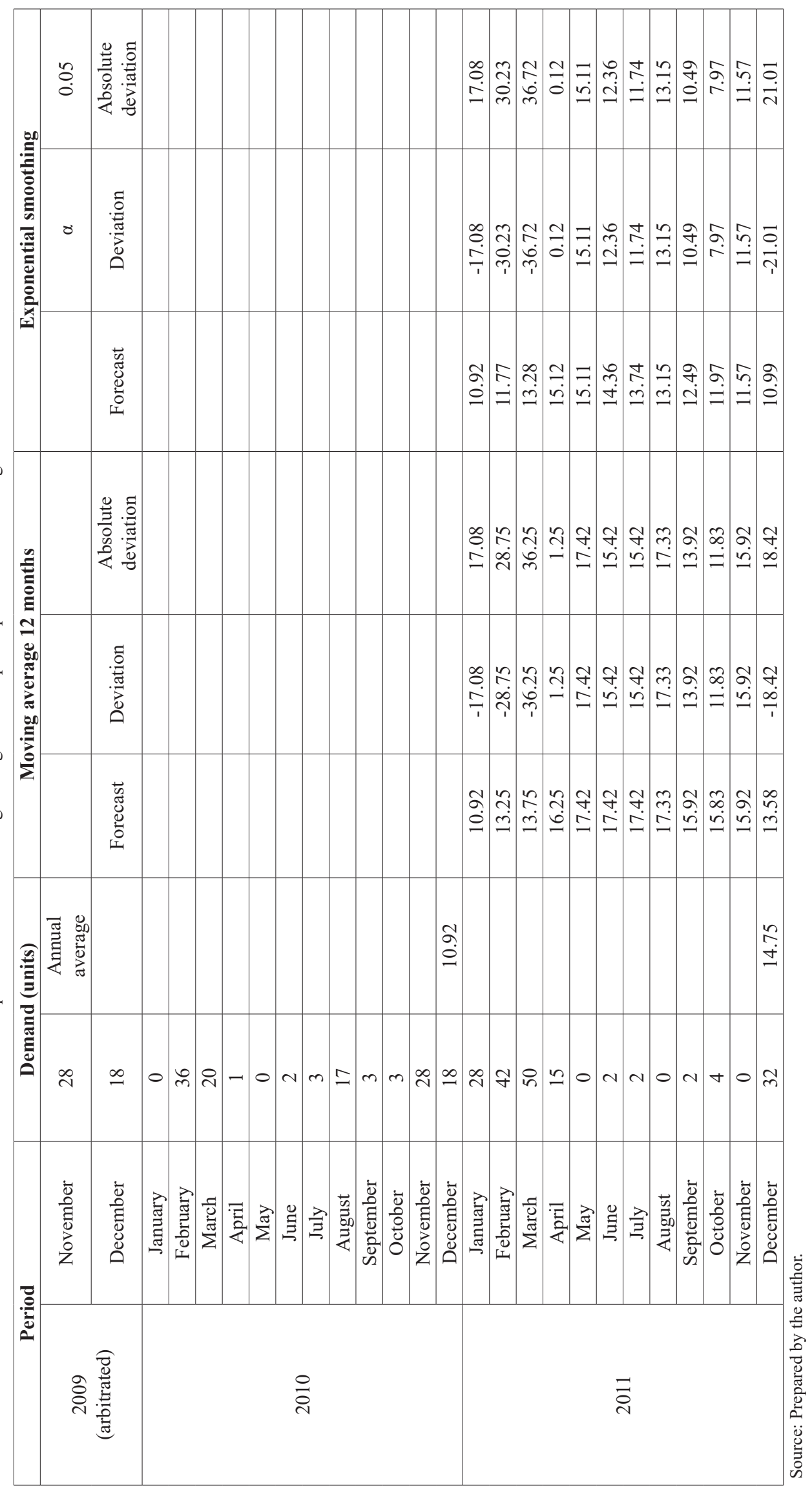




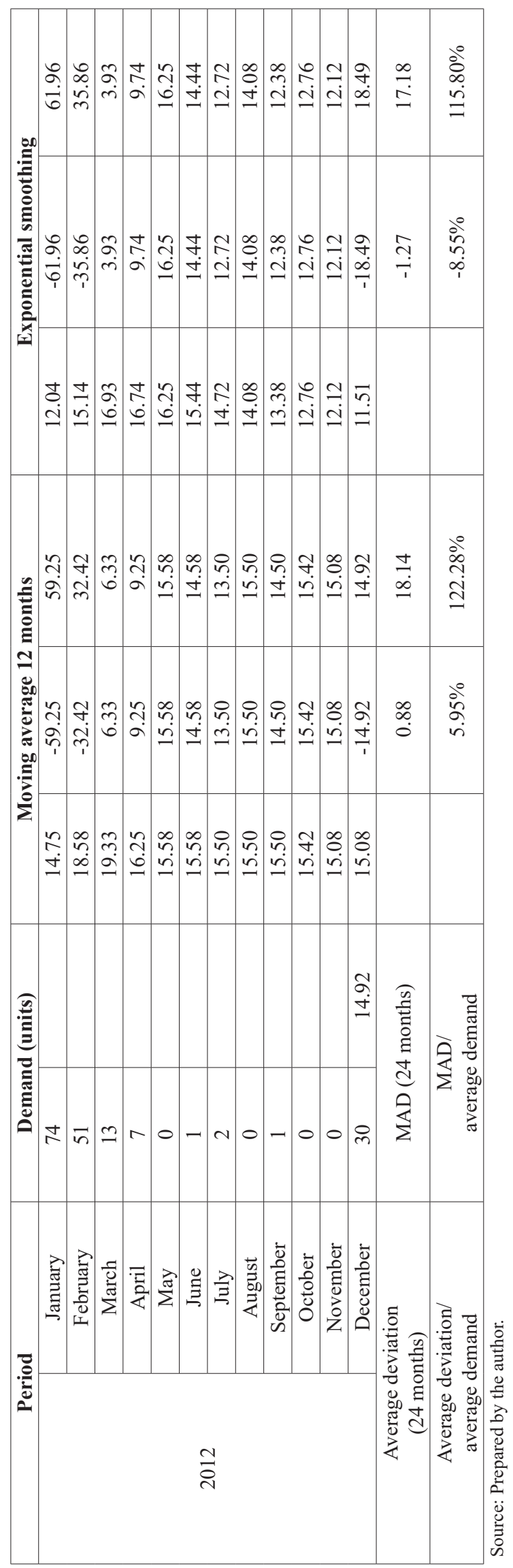




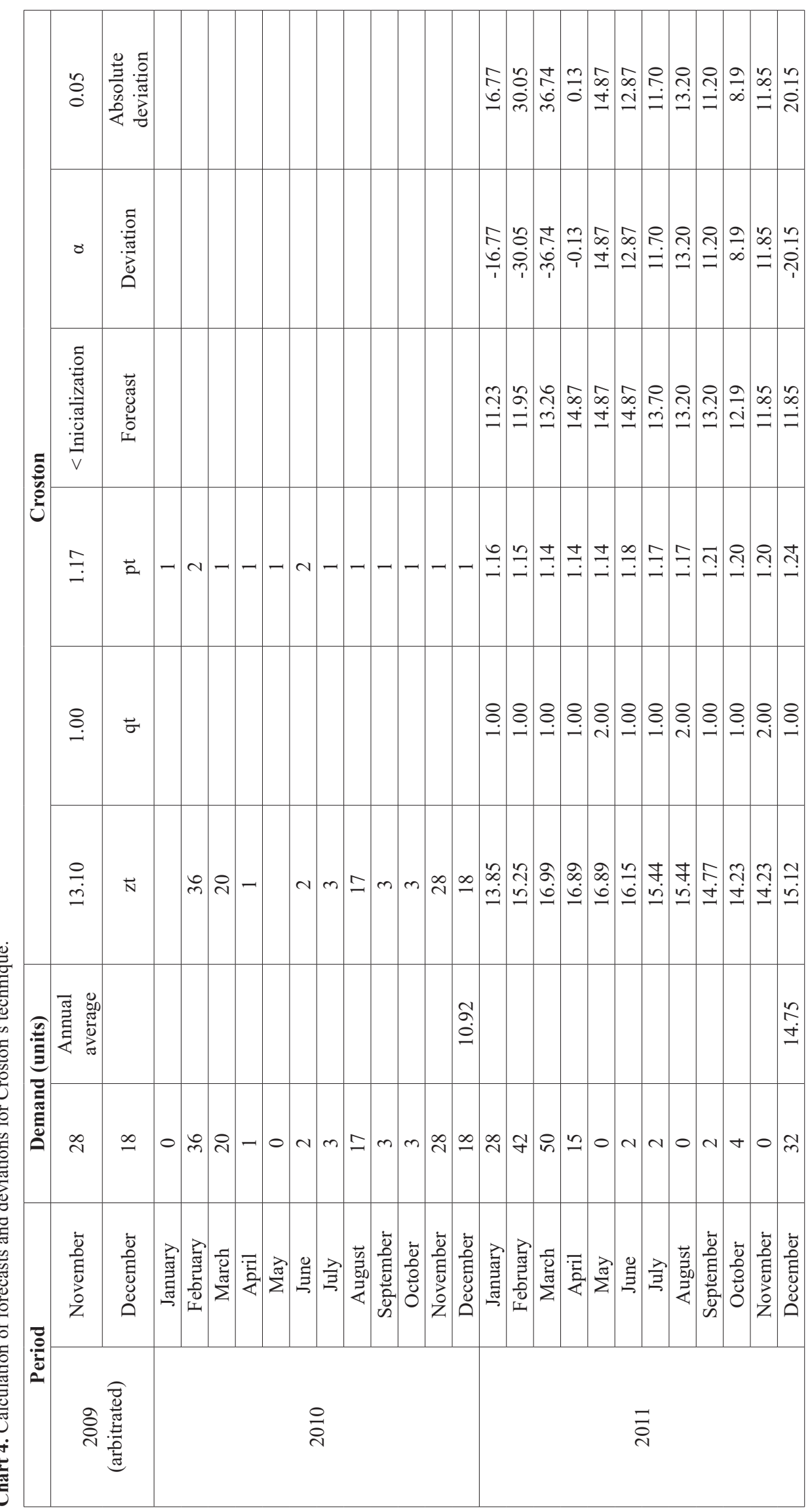




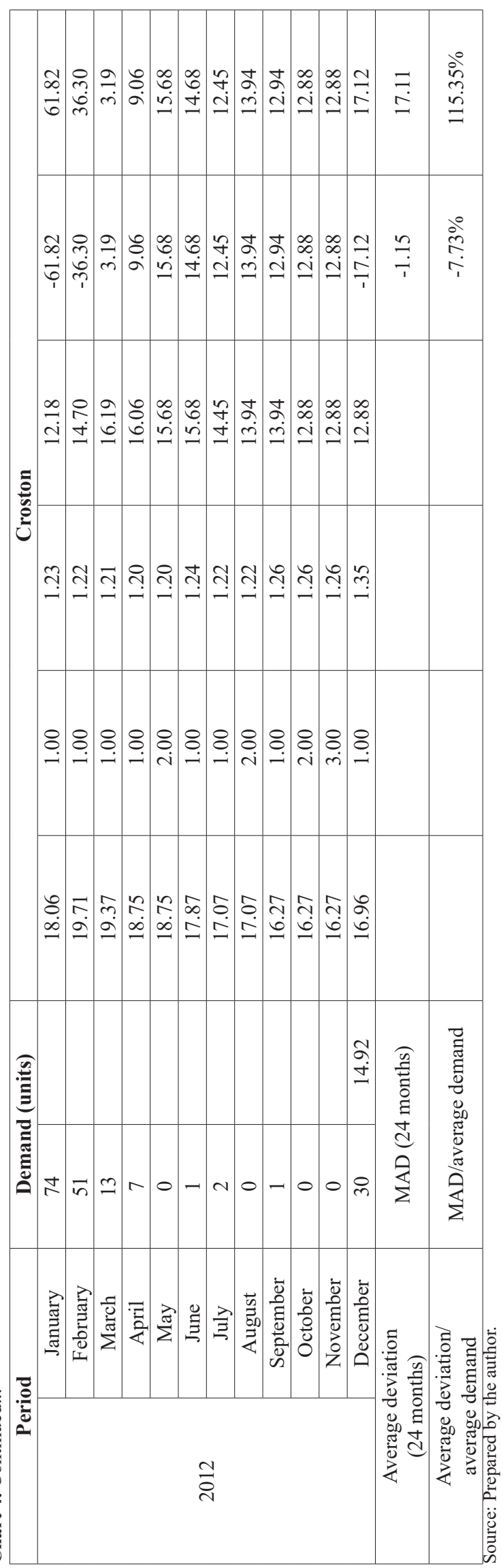




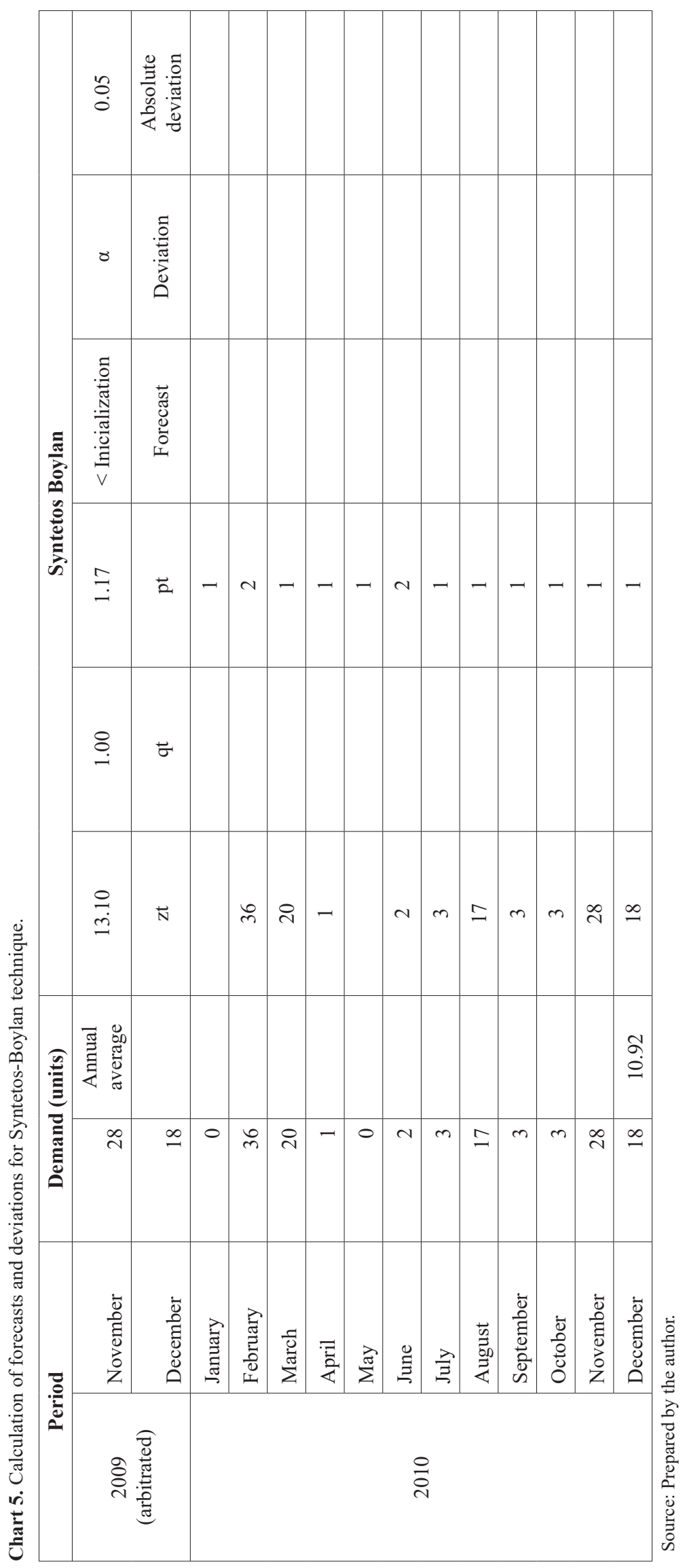




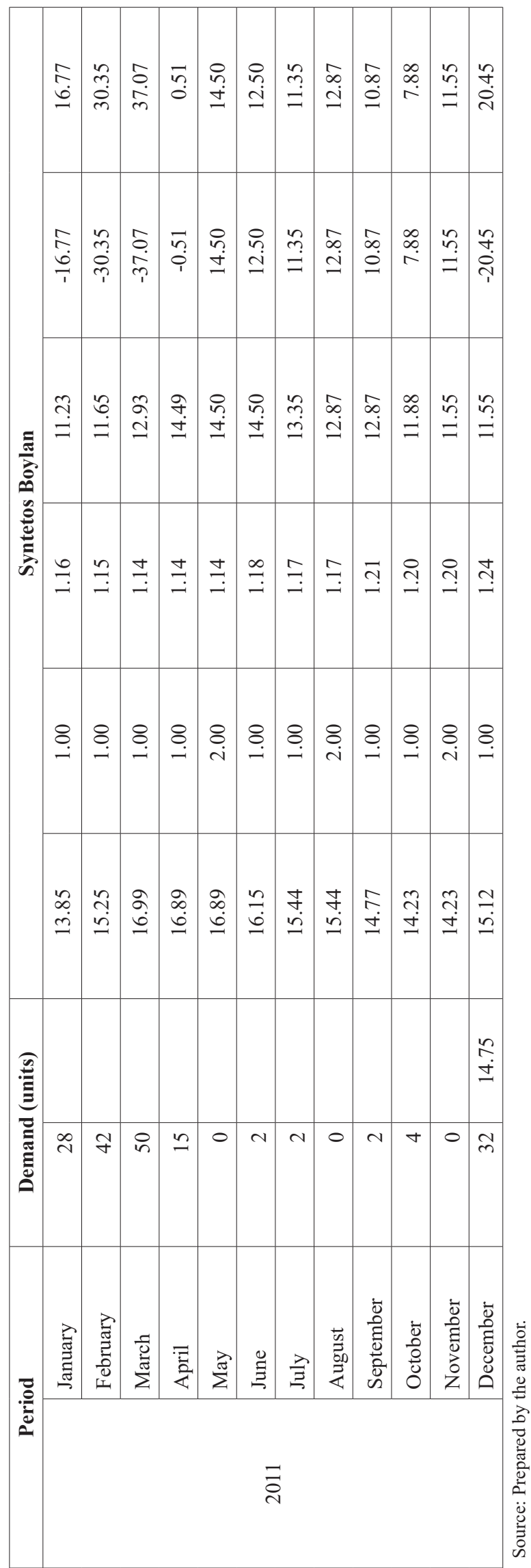




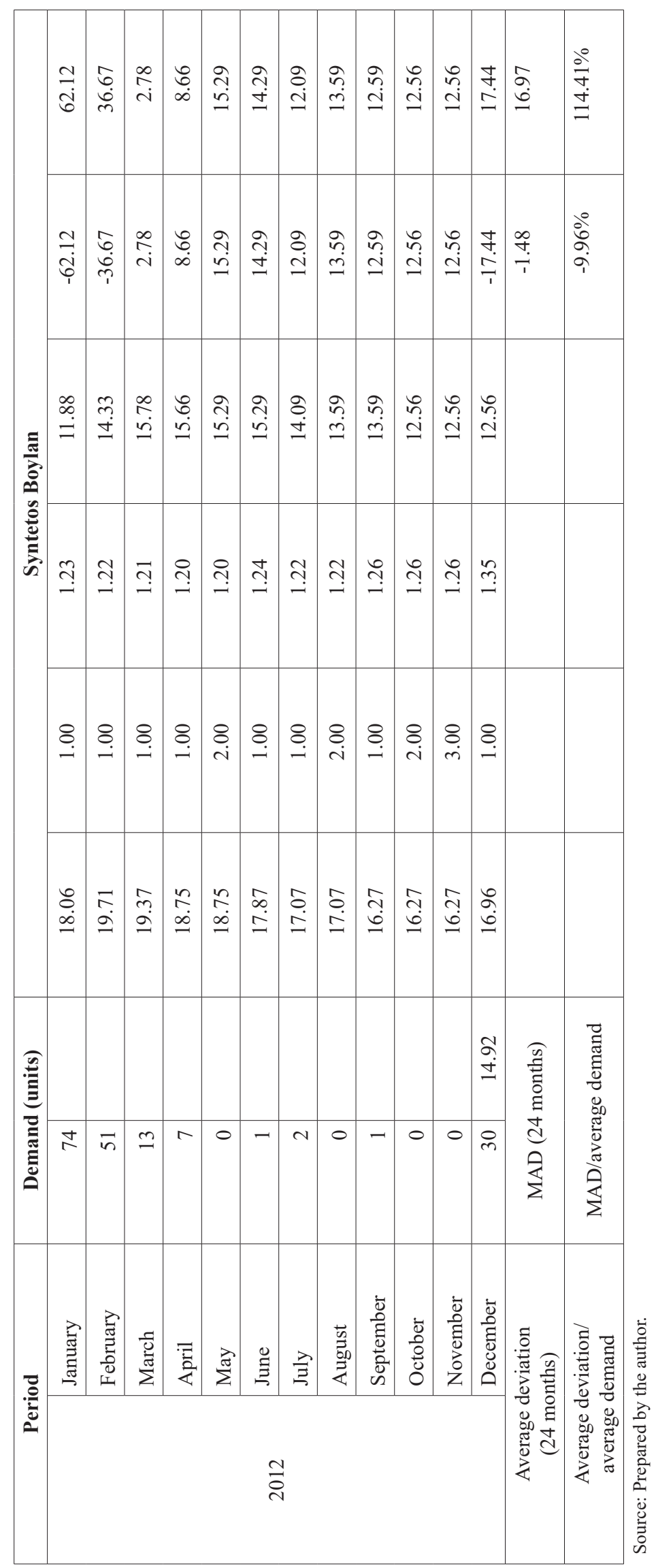


Table 4. Comparative summary.

\begin{tabular}{|c|c|c|c|c|}
\hline Technique & $\begin{array}{c}\text { Average } \\
\text { deviation } \\
(24 \text { months }) \\
\end{array}$ & $\begin{array}{c}\text { Average } \\
\text { deviation/ } \\
\text { average demand }\end{array}$ & $\begin{array}{c}\text { MAD } \\
\text { (24 months) }\end{array}$ & $\begin{array}{l}\text { MAD/ } \\
\text { average demand }\end{array}$ \\
\hline $\begin{array}{l}\text { Semestral seasonality factor with monthly } \\
\text { basis }\left(\gamma=0.30 ; \alpha^{\prime}=0.10 ; \alpha=0.05\right)\end{array}$ & -2.48 & $-16.74 \%$ & 11.81 & $79.62 \%$ \\
\hline $\begin{array}{l}\text { Exponential smoothing with semestral } \\
\text { grouping }(\gamma=0.30 ; \alpha=0.05)\end{array}$ & -2.70 & $-18.19 \%$ & 11.49 & $77.49 \%$ \\
\hline Moving average 12 months & 0.88 & $5.95 \%$ & 18.14 & $122.28 \%$ \\
\hline Exponential smoothing $(\alpha=0.05)$ & -1.27 & $-8.55 \%$ & 17.18 & $115.80 \%$ \\
\hline Croston $(\alpha=0.05)$ & -1.15 & $-7.73 \%$ & 17.11 & $115.35 \%$ \\
\hline Syntetos Boylan $(\alpha=0.05)$ & -1.48 & $-9.96 \%$ & 16.97 & $114.41 \%$ \\
\hline
\end{tabular}

Source: Prepared by the author.

with semestral basis, where the estimate for each month of the semester is equal, provided a Mean Absolute Deviation that was slightly smaller than that of smoothing with monthly update of the basis and semestral update of the seasonality factor $(11,49$ versus 11,81$)$, and the opposite occurred with the average error ( -2.70 versus -2.48$)$, thus indicating that the technique proposed showed to be slightly less biased, although a little less accurate.

The potential of the technique herein proposed may reside in the fact that the estimates of each month within the same semester are different and may follow some growth (and later reduction) of demand within a period with the same seasonality factor. This benefit may be particularly more pronounced in the cases in which this period is long. Companies frequently use weekly basis to update demand, and updating the basis with this frequency, in a situation where seasonality is quarterly or semestral, could make the proposed technique useful.

\section{References}

Ballou, R. H. (2006). Gerenciamento das cadeias de suprimentos: logística empresarial. Porto Alegre: Bookman.

Biazzi, J. L., \& Vital, M. (2013). Gestão de estoques para peças de reposição de baixo consumo em empresa do setor Bioenergético Sucroalcooleiro. In Anais do XVI Seminários em Administração (SemeAd). São Paulo: SemeAd. Recuperado em 25 de fevereiro de 2014, de http://www.semead.com.br/16semead/resultado/ an resumo.asp? cod trabalho $=438$

Bowersox, D. J., \& Closs, D. J. (2001). Logística empresarial: o processo de integração da cadeia de suprimento. São Paulo: Atlas.

Chase, R. B., Jacobs, F. R., \& Aquilano, N. T. (2006). Administração da produção para a vantagem competitiva (10. ed.). Porto Alegre: Bookman.
Chopra, S., \& Meindl, P. (2003). Gerenciamento da cadeia de suprimentos: estratégia, planejamento e operação. São Paulo: Prentice Hall.

Codogno, V. (2016, 27 de janeiro), O mercado de sorvetes pós-paleta. São Paulo: O Estado de S. Paulo. Recuperado em 11 de novembro de 2016, de http://pme.estadao. com.br/noticias/noticias,o-mercado-de-sorvetes-pospaleta, $6215,0 . \mathrm{htm}$

Croston, J. D. (1972). Forecasting and stock control for intermittent demands. Operational Research Quarterly, 23(3), 289-303. http://dx.doi.org/10.2307/3007885.

De Gooijer, J. G., \& Hyndman, R. J. (2006). 25 years of time series forecasting. International Journal of Forecasting, 22(3), 443-473. http://dx.doi.org/10.1016/j. ijforecast.2006.01.001.

Dekker, M., Van Donselaar, K., \& Ouwehand, P. (2004). How to use aggregation and combined forecasting to improve seasonal demand forecasts. International Journal of Production Economics, 90(2), 151-167. http://dx.doi.org/10.1016/j.ijpe.2004.02.004.

Gardner, E. S., Jr. (1985). Exponential smoothing: the state of the art. Journal of Forecasting, 4(1), 1-28. http:// dx.doi.org/10.1002/for.3980040103.

Gardner, E. S., Jr. (2006). Exponential smoothing: the state of the art: Part II. International Journal of Forecasting, 22(4), 637-666. http://dx.doi.org/10.1016/j. ijforecast.2006.03.005.

Gould, P. G., Koehler, A. B., Ord, J. K., Snyder, R. D., Hyndman, R. J., \& Vahid-Araghi, F. (2008). Forecasting time series with multiple seasonal patterns. European Journal of Operational Research, 191(1), 207-222. http://dx.doi.org/10.1016/j.ejor.2007.08.024.

Krajewski, L. J., Ritzman, L., \& Malhotra, M. (2009). Administração de produção e operações. São Paulo: Pearson Prentice Hall.

Makridakis, S., Wheelwright, S. C., \& Hyndman, R. J. (1998). Forecasting: methods and applications (3rd ed.). Hoboken: John Wiley \& Sons. 
Rego, J. R., \& Mesquita, M. A. (2011). Controle de estoques de peças de reposição: uma revisão literária. Produção, 21(4), 645-655. http://dx.doi.org/10.1590/ S0103-65132011005000002.

Silver, E. A., Pyke, D. F., \& Peterson, R. (1998). Inventory management and production planning and scheduling. New York: Wiley.

Syntetos, A. A., \& Boylan, J. E. (2001). On the bias of intermittent demand estimates. International Journal of Production Economics, 71(1-3), 457-466. http://dx.doi. org/10.1016/S0925-5273(00)00143-2.

Syntetos, A. A., \& Boylan, J. E. (2005). The accuracy of intermittent demand estimates. International Journal of Forecasting, 21(2), 303-314. http://dx.doi.org/10.1016/j. ijforecast.2004.10.001.

Taylor, J. W. (2010). Triple seasonal methods for short-term electricity demand forecasting. European Journal of
Operational Research, 204(1), 139-152. http://dx.doi. org/10.1016/j.ejor.2009.10.003.

Wanke, P. (2003). Gestão de estoques na cadeia de suprimento: decisões e modelos quantitativos. São Paulo: Atlas.

Willemain, T. R., Smart, C. N., \& Schwarz, H. F. (2004). A new approach to forecasting intermittent demand for service parts inventories. International Journal of Forecasting, 20(3), 375-387. http://dx.doi.org/10.1016/ S0169-2070(03)00013-X.

Yager, R. R. (2013). Exponential smoothing with credibility weighted observations. Information Sciences, 252, 96-105. http://dx.doi.org/10.1016/j.ins.2013.07.008.

Yelland, P. M. (2010). Bayesian forecasting of parts demand. International Journal of Forecasting, 26(2), 374-396. http://dx.doi.org/10.1016/j.ijforecast.2009.11.001. 